\title{
Land use changes after the period commodities rising price in the Rio Grande do Sul State, Brazil
}

\author{
Vicente Celestino Pires Silveira ${ }^{1}$ José Antonio González ${ }^{2}$ Eliana Lima da Fonseca ${ }^{3}$
}

\footnotetext{
'Departamento de Educação Agrícola e Extensão Rural, Universidade Federal de Santa Maria (UFSM), Santa Maria, RS, Brasil. ${ }^{2}$ Laboratorio de Socio-ecosistemas, Departmento de Ecología, Universidad Autónoma de Madrid, Madrid, España.

${ }^{3}$ Departamento de Geografia, Universidade Federal do Rio Grande do Sul (UFRGS), Porto Alegre, RS, Brasil.
}

\begin{abstract}
At the end of the 20th and early 21st century, agricultural systems incorporated definitively a new mission: to generate goods for a world population that continues to grow and whose way of life demand food with low environmental impact. Soybean is the main raw material for the production of biodiesel in Brazil, accountably responsible for 82.4\% of the total produced between 2006 and 2013. The Brazilian state of Rio Grande do Sul (RS), which is formed by the Pampa and the Atlantic forest biomes, was responsible for 35.7\% of the country's biodiesel production in the referred period. The aim of this paper was to verify the impact of the increased area of soybean cultivation in land use in Rio Grande do Sul State, in the period between 1990 and 2015 , considering separately its two biomes (Pampa and Atlantic Forest) original areas, using both census dataset and satellite images. We used the period from 1990 to 2000 as before commodity rising price (BCRP) and the period from 2000 to 2013 as commodity rising price (CRP). The 505,162 ha from Atlantic Forest biome and 1,192,115ha from Pampa biome were added to soybean production in the CRP period. In the Atlantic Forest, this enlargement occurred in the border of the main production area, while in Pampa biome conversion of natural grassland to crop land was the main reason for the large increment in the cultivated area. Key words: Pampa biome, Atlantic Forest Biome, biodiesel, soybean cultivation, commodity prices.
\end{abstract}

\section{Mudanças no uso da terra depois do período de aumento de preço} das commodities no Rio Grande do Sul, Brasil

RESUMO: No final do século XX e início do século XXI, os sistemas agrícolas incorporaram definitivamente uma nova missão: gerar energia para uma população mundial que continua a crescer e que demanda por seu modo de vida, não só alimentos, mas também, cada vez mais energia, principalmente, energia com baixo impacto ambiental. A soja permaneceu a principal matéria-prima para a produção de biodiesel no Brasil, no período de 2006 a 2013 , em que foi responsável por 82,4\%, sendo o estado do RS responsável por 35,7\% do total da produção brasileira de biodiesel. O objetivo deste trabalho é verificar o impacto do aumento da área de cultivo de soja no uso da terra no Rio Grande do Sul, no periodo entre 1990 e 2015. Considera-se, separadamente, as áreas originais de seus dois biomas (Pampa e Mata Atlântica), usando o conjunto de dados do IBGE e imagens de satélite. Utilizou-se o período de 1990 a 2000 como o período anterior ao da suba de preços de commodities (BCRP) e, o período de 2000 a 2013 como período de aumento do preço das commodities (CRP). Um total de 505.162ha do bioma Mata Atlântica e de 1.192.115ha do bioma Pampa foram incorporados à produção de soja no período CRP. No bioma Mata Atlântica, o aumento ocorreu nos limites da área cultivada, enquanto que no bioma Pampa através da conversão da área com pastagem nativa. Palavras-chave: Bioma Pampa, Bioma Mata Atlântica, biocombustivel, soja, preço commodities.

\section{INTRODUCTION}

Although climate and natural resources have significantly shaped the development of civilizations throughout history, in anthropogenic societies human activities impact on - and in many cases dominate - the regulation of climate, biogeochemical cycles and biodiversity, all of which are essential to human life (STEFFEN et. al, 2007). Uncertainty about interactions and feedbacks between the natural and human drivers of environmental change that may operate at different spatial and temporal scales make difficult for societies to solve an appropriate course of collective action to pursue sustainable livelihoods. (SANTOS-MARTIN et al., 2013).
At the end of the 20th and early 21st century, agricultural systems incorporated definitively a new mission: generate goods for a world population that continues to grow and whose way of life demand food with low environmental impact. In parallel, an over-a-century long trend of declining agricultural commodity prices has ended. The turn of the millennium has marked a mega trend reversal in international agricultural commodity markets. Since then, commodity prices in international agricultural markets tended to rise - with significant fluctuations as in the past. The reason for the upward trend in prices is simply that global demand growth is outpacing growth in supply (VON WITZKE \& NOLEPPA, 2014). 
Rio Grande do Sul (RS) is the state located further south in Brazil, with two different biomes: the Pampa biome in the southern half of the state, and the Atlantic Forest biome at north. Pampa biome was part of the Rio de la Plata grasslands, the largest complex of temperate grassland ecosystems in South America, comprising an area of approximately $750,000 \mathrm{~km}^{2}$ (SORIANO et al. 1992). In the Pampa biome the original natural grassland vegetation has been completely replaced in at least $50 \%$ of the area (OVERBECK et al., 2013). Atlantic Forest biome is the biggest costal biome in Brazil and it only conserves $7.5 \%$ of the original vegetation, highly fragmented (SEPLAN, 2015).

Soybean has become one of the world's most important agroindustrial commodities - serving as the nexus for the production of food, animal feed, fuel and hundreds of industrial products - and South America has become its leading production region actually (OLIVEIRA \& HECHT, 2016). Soybean is the main raw material for the production of biodiesel in Brazil, accountably responsible for $82.4 \%$ of the total produced between 2006 and 2013. The Rio Grande do Sul State was responsible for $35.7 \%$ of total Brazilian biodiesel production in 2015 (ANP, 2015). Biofuels can replace vast areas of farmland and native habitats, driving up food prices and resulting in little reduction or even increasing greenhouse gas emissions (LAPOLA et. al., 2010). As described by CONCEIÇÃO (1984); although, soybean cultivation experienced a widespread outbreak of expansion between 1950 and 1975 in RS, it was mainly concentrated in Northern and Western regions. This can be directly linked to the fact that soybean cultivation in Brazil was originated from those regions. Therefore, at that time the pressure of expansion occurred mainly in Atlantic Forest biome. To increase production at the beginning of the $21 \mathrm{st}$ century in the Pampa region, some changes were required in order to overcome physical and social restrictions. According to PIZZATO (2013), these changes were: a) presence of techniques to transpose the soil characteristics, that were previously slightly directed to agriculture; b) search for more affordable land; c) increasing selection of cultivars adapted to the region; d) replacement of land property from the beef cattle farming model to the land leasing model; and e) emergence of new actors determined to invest in this new agricultural frontier.

These territorial changes observed in the RS state came from a new cycle of profound structural transformation that began to take shape in rural areas of the South American region in the 1990s, the large- scale agriculture. The expansion of agribusiness in Latin America can be attributed to two dynamics. On one hand, the increase in domestic consumption in nearby countries with strong economic and population growth, and on the other hand new emerging Asian markets such as China. In this context, the production of so-called flexible crops, such as soybean, has gained importance. This flexibility in the economic use has become a central component of global supply chains (GRAS \& GÖBEL, 2014).

KOHLHEPP (2010) highlighted several important limitations of the use of soybean, to be considered from ecological and social perspectives. Among these "shadows" of soybean cultivation are: planting monocultures by landowners; concentration of property and massive oppression against small producers and numerous land conflicts; overuse of agrochemicals and consequent contamination of water; high mechanization and little hand demand work; as well as competition for land use with producers of basic foodstuffs. Moreover, it has been proved that the homogenization of the agrarian landscape leads to the emptying of the countryside and strengthens the migration of the excluded to the circuit of urban poverty.

Changes in land use and land cover represent a complex environmental, socioeconomic, and technological problem. Conversely, agriculture is essential to human subsistence as provides food, fibers, fuels, construction materials and globally enhances economic development for human welfare. Agricultural activities generated cascading impacts that modify the fluxes of energy and materials, structure and functioning of natural ecosystems, and supply of goods and services, affecting human wellbeing (BALDI \& PARUELO, 2008).

The aim of this paper is to verify modifications in land use in the state of Rio Grande do Sul, due to the increased area of soybean cultivation between 1990 and 2015. The original areas of the two biomes in RS (Pampa and Atlantic Forest) were considered separately, using both census datasets and satellite images.

\section{METHODOLOGY}

We distinguished two periods for the analyses. The period from 1990 to 2000 was assigned as "before commodity rising price" (BCRP), and the period ranging from 2000 to 2015 as "commodity rising price" (CRP). Those periods were defined considering the statement made by VON WITZKE $\&$ NOLEPPA (2014) that the turn of the millennium 
produced a mega reversal trend in international agricultural commodity prices that tended to rise.

The cultivation area and animal dataset was obtained from the SIDRA database available at the Brazilian Institute of Geography and Statistics (IBGE). Data related to four hundred and ninety-seven municipalities in Rio Grande do Sul State, classified by cropland type and by animal product type was collected for each year over the time series (1990 to 2013).

Municipalities of RS were allocated to the Pampa or the Atlantic Forest biome, using a GI system (QGIS, version 2.8.6) by an automatic overlay analysis using two vector layers: the Brazilian biome map and the Rio Grande do Sul State municipalities map. One hundred and sixteen municipalities were allocated to the Pampa Biome, with a total of $176,542 \mathrm{~km}^{2}$, very similar to the area considered by the Ministry of Environment $\left(176,496 \mathrm{~km}^{2}\right.$; MMA, 2015). Three hundred and eighty-one municipalities were allocated to the Atlantic Forest, comprising a total area of $105,297 \mathrm{~km}^{2}$.

After establishing which municipalities constituted each biome, the total number of hectares cultivated for each crop in the period between 1990 and 2013 was calculated. Annual values for summer cash crops (beans, rice, sorghum, soybean and sunflower) and winter cash crops (barley, oat, rye and wheat) were obtained. Then, total herd of cattle and sheep and cattle milk production were calculated. Milk production was used as an indirect indicator of the dairy cattle herd, which enables the estimation of the impact of soybean cultivation also in dairy cattle. Graphs were made for each variable for the time series, to identify the impact of land use in the biomes original areas.

For a better understanding of where those detected changes are, summer cropland maps for cropyears 2000/01 and 2014/15 were made using satellite images automatic classification and a difference map showing the detected changes was made using map algebra. For each crop-year satellite images acquired in two different dates were necessary to obtain the final map: an image from November to identify the bare soil and an image from March to verify if the bare soil has vegetation cover or not, allowing to the summer croplands map (SANTOS et al., 2014). We used NDVI images (Normalized Difference Vegetation Indice) from MODIS sensor (Moderate Resolution Imaging Spectroradiometer) that cover all the RS area. Those images are distributed in georreferenced products with $250 \mathrm{~m}$ of spatial resolution where each image pixel has a MVC (Maximum Value Composite) of 16 days (NASA, 2016).
The ISODATA automatic classification algorithm in the SPRING software (5.6 version) was used to identify the natural targets (vegetation, bare soil and water) in NDVI images. Considering that NDVI values from -1 to 0 are related with water, 0 to 0,3 with bare soil (or areas without vegetation) and 0,3 to 1 with vegetation (JONES \& VAUGHAN, 2010) and the image spatial resolution, the parameters used to ISODATA algorithm was set as 0,1 values to similarity and 1 pixel to area, with 5 iterations. We made four maps for all the RS state area (November - 2000, March - 2001, November - 2014, March 2015) which were used to generate the crop-years 2000/01 and 2014/15 by map with Boolean logic. For each crop-year those areas classified with bare soil on November and with vegetation on March were reclassified as summer cropland. For each crop-year we also generated a summer cropland map over each analyzed biome (summer cropland map over and over Atlantic Forest biome both for 2000/01 and 2014/15). For each biome a difference map was built using arithmetic map algebra, allowing to identify the place where occurred detected changes.

\section{RESULTS}

There is a perceptible change in the tendency and amount of land use allocated for summer cash crops between BCRP and CRP period (Figure 1). In the Atlantic Forest biome 505,162ha were added, most of them from the reduction of land cultivated with corn $(403,222 \mathrm{ha})$ and beans (88,386ha). In the Pampa biome increase of soybean cultivation was $1,192,115$ ha and the reduction of corn and bean cultivation areas were 100,809 and 23,197ha, respectively. Rice was the main cash crop in the Pampa Biome in BCRP, and the area for cultivation increased in 124,897ha during CRP. However, this was not enough for it to continue as the main cash crop. In 2003, soybean also became the main cash crop in the Pampa. Sunflower cultivation was stimulated by government programs to produce biodiesel alongside soybean, but was not well received by farmers in both biomes (Figure 1). As an indirect effect of increase land use with cash crop during summer, the cultivated area also increased in winter in the Atlantic Forest and Pampa, being wheat the main crop planted.

Alterations between the BCRP and CRP period were not verified for cattle herd with similar curve tendency in both periods (Figure 2). However, milk production, mainly in the Atlantic Forest increased on both periods. 


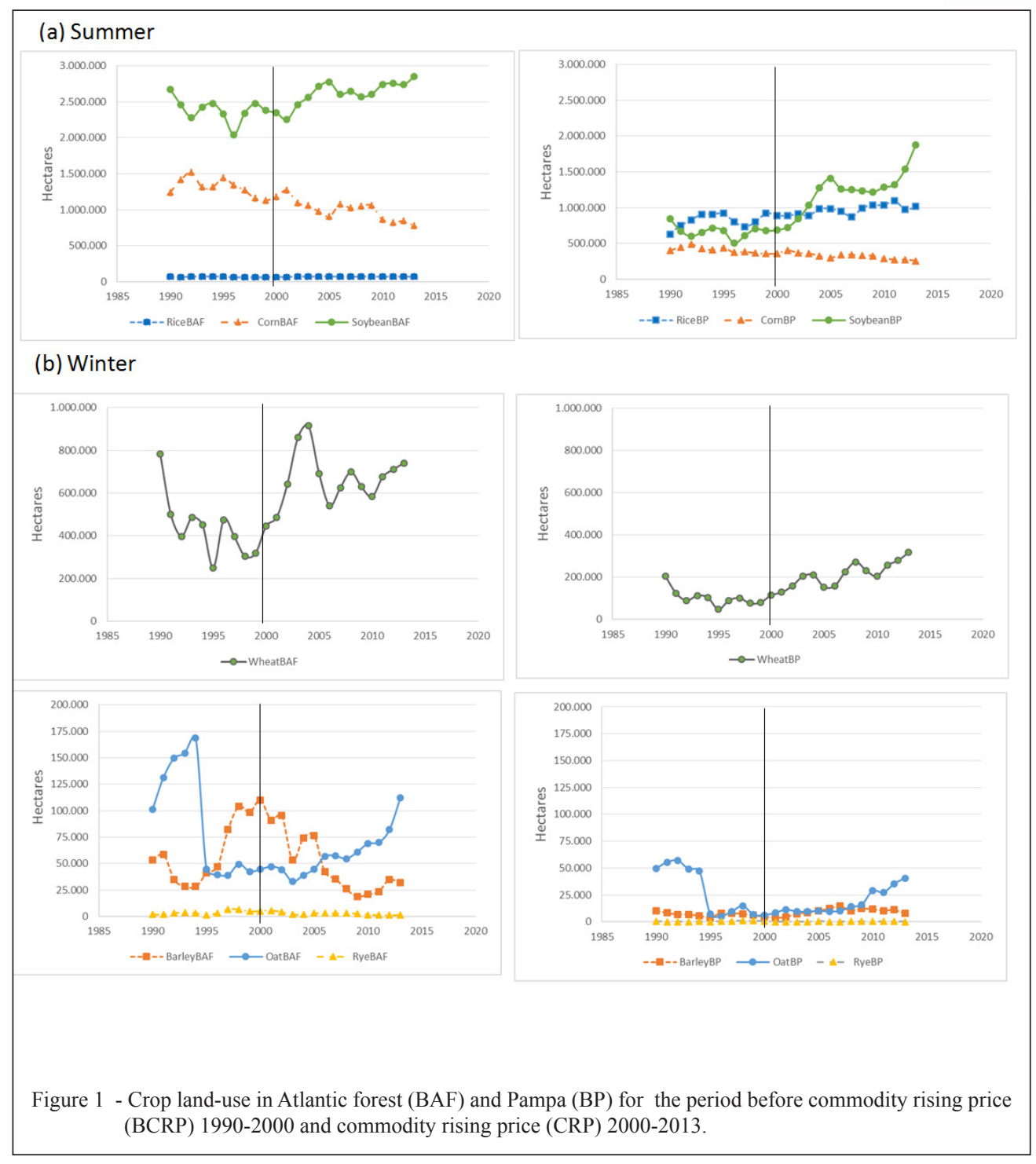

The summer croplands areas in the Atlantic Forest biome were 3,047,351 ha for 2000/01 and $3,419,850$ ha for $2014 / 15$, with an increase of 372,499ha (or 12.2\%) during 15 years (Figure 3). In the Pampa biome the summer croplands areas were 2,691,322ha for $2000 / 01$ and 4,225,572ha for 2014/15, with an increase of 1,534,249ha (or $57.0 \%$ ) for the same time period. In the Atlantic Forest, this enlargement occurred in the border of the main production area, while in the Pampa biome the conversion of natural grassland to cropland was the main reason for the large increment in the cultivated area.

\section{DISCUSSION}

Farmer decision-making researches try to explore which variables lead farmers to adopt an innovation, to choose for crop cultivation or breed herding. Nevertheless, land use is still a good indicator for the result of these decisions. As we can see, the land cultivated with soybean increases in both biomes in the CRP period (Figure 1). In Pampa biome around one million hectares came from area occupied by natural grassland used for grazing by cattle and sheep, which can result in increasing carbon emission from the soil. LAPOLA et al. (2010) sustained that carbon emissions 


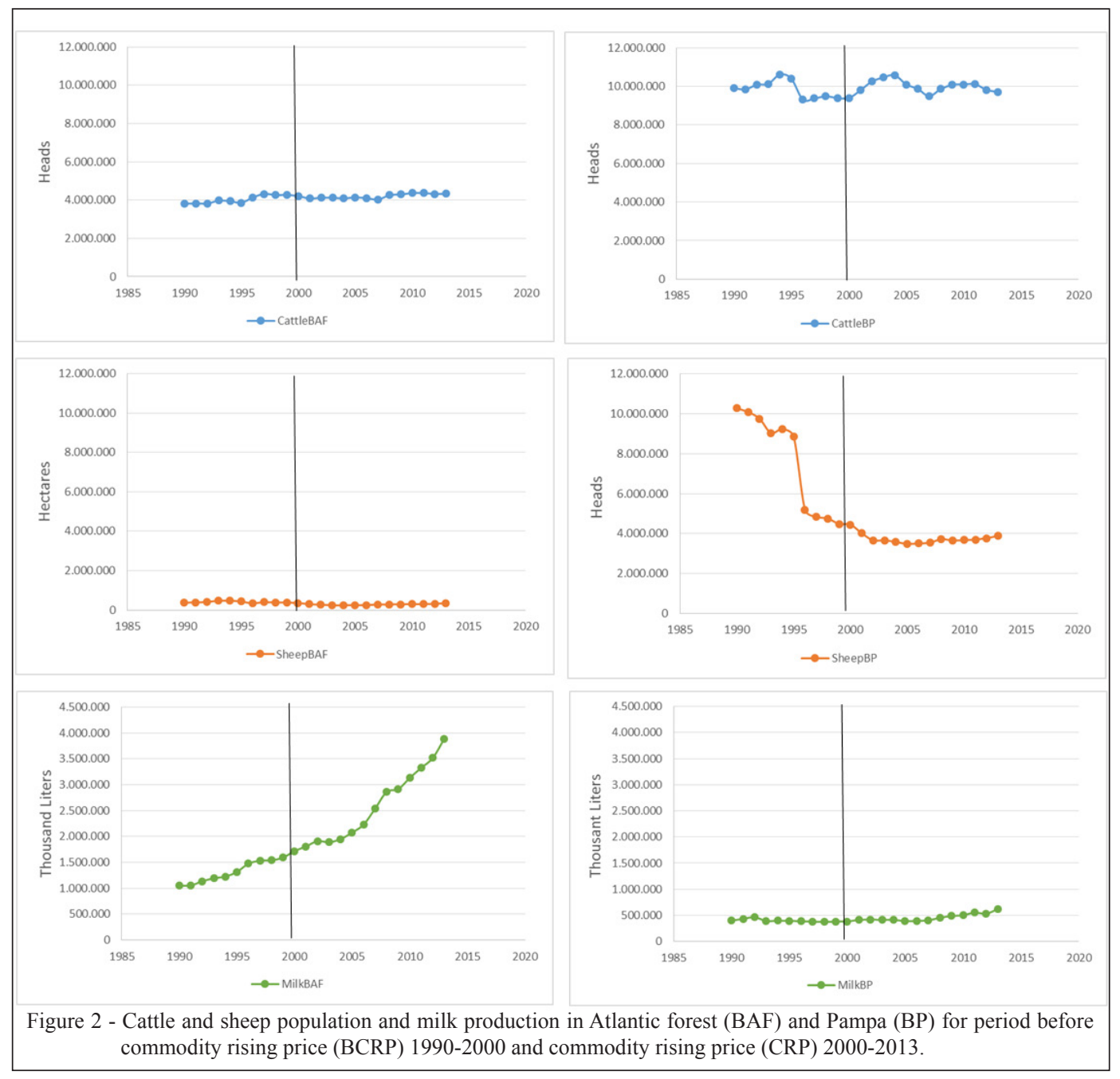

would change negatively from soil carbon losses when converting rangeland to sugarcane or soybean plantations. Thus, conversion of large areas to plant biofuel crops may place additional pressures on the environment (RIGHELATO \& SPRACKLEN, 2007).

Indirect effect of increased soybean area for summer crash crop during cold season was also evaluated. Area cultivated with wheat increased in both biomes in the CPR period, but only in the Pampa biome had significant effects, probably due to the continuously rising area of wheat cultivation after summer soybean cultivation (Figure 1). Land cultivated with wheat increased in the RS State, being that these results diverge with the ones obtained from the European Union countries where the rapeseed seems to be the main source of biodiesel and competes for land with wheat (MITCHELL, 2008; UFOP, 2015). Oat cultivation increased significantly in both biomes. One consideration needs to be made, that oat cultivation is also used in animal systems production, mainly for dairy cattle and finishing beef cattle.

A reduction in the sheep wool in BCRP (Figure 2) was observed for Pampa Biome as a result from the biggest period of downfall, which started at the end of the 1980's due to the high supplies of Australian wool and the beginning of the commercialization of synthetic fibers in the international textile market. The crisis extended itself throughout the 1990's, which made many farmers give up the activity, reducing significantly the commercial wool production, causing the destructuralization of the production chain. However, the increase in the purchasing power of the population and the increase in the number of young animals slaughtered opened a meat market for sheep farming (VIANA et al., 2012). 


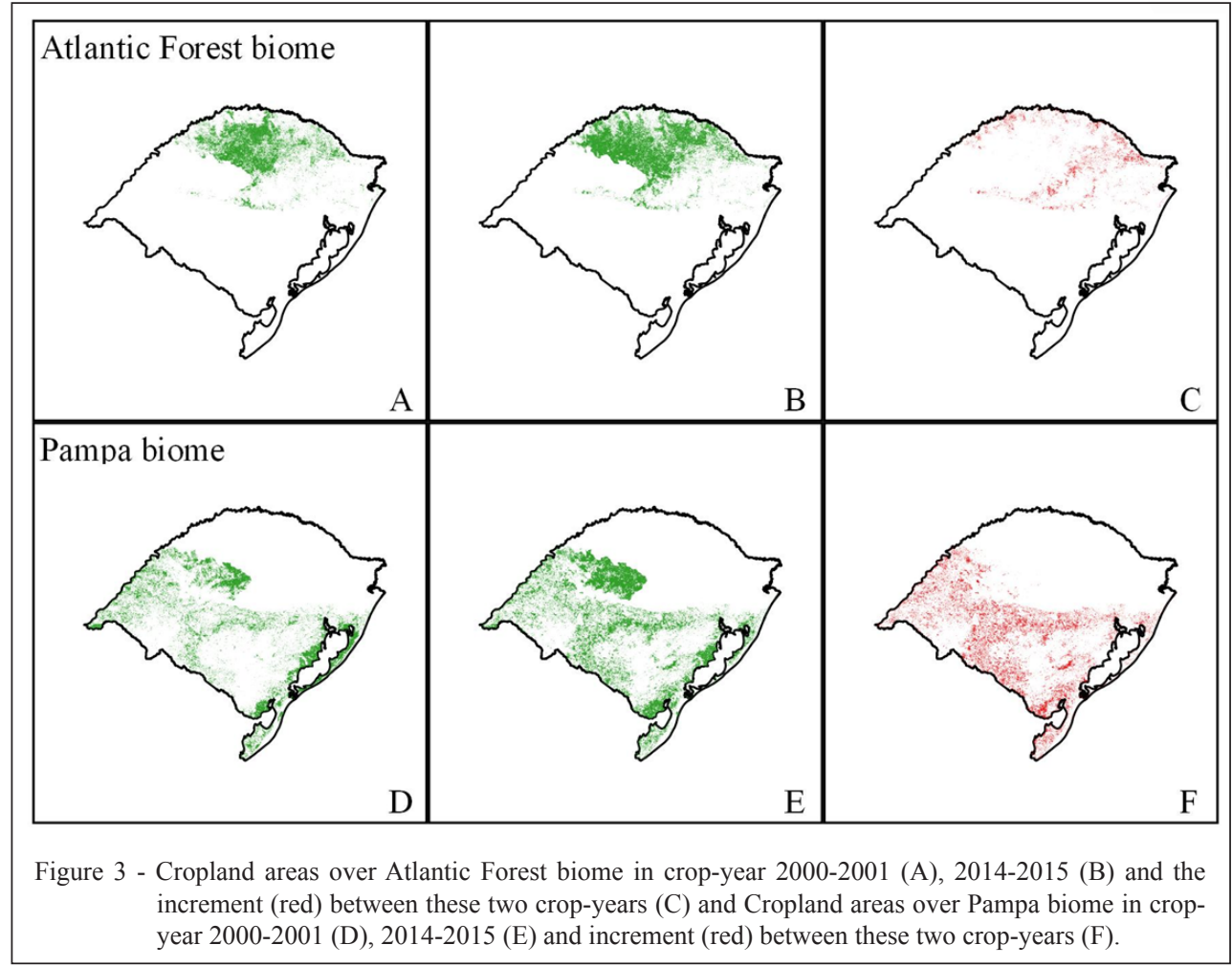

When the number of sheep stabilizes, a change to meat market for the CRP period can be observed.

The Atlantic Forest concentrates the dairy herd in the state. According to BREITENBACH \& SOUZA (2011), from 2004 onwards there was an increase of dairy industries in the region, attracted by the abundance of raw material (Figure 2). In this region, milk production systems occurred in intensive way with high productivity and use of concentrates, pastures and silage (MAIXNER, 2006; EMBRAPA, 2008).

The central pivot of the land use transition to more environmentally friendly agriculture in Brazil resulted in land being saved for other uses. However, this option has to be carefully evaluated, given that - in light of land rent theory - agricultural intensification and its increased economic attractiveness leads to expansion, rather than contraction of cultivated and grazing land (LAPOLA et al., 2014). Results obtained indicated this situation in the RS State. Increase of soybean cultivation replaces land used for cultivating corn and bean in Atlantic Forest. In Pampa, contrarily, advances occur on natural grassland areas, which concurs with the process described in the Rio de la Plata grassland ecosystem (GAS \& GÖBEL, 2014).

\section{CONCLUSION}

Proportion of land in the Atlantic Forest and Pampa regions dedicated to soybean cultivation in Rio Grande do Sul state had increased along the time studied, but specially after the year 2000, when started the commodity rising price. In the Atlantic Forest, this enlargement occurs in the border of the main production area, while in the Pampa biome the conversion of natural grassland to cropland was the main reason for the large increment in the cultivated area. Despite of a decrease in natural grassland area in the Pampa biome, the number of cattle and sheep does not decrease, indicating an intensification of animal production systems.

\section{REFERENCES}

ANP. Boletim mensal do biodiesel. Available from: $<$ http://www. anp.gov.br/?pg $=74335 \& \mathrm{~m}=$ boletim $\& \mathrm{t} 1=\& \mathrm{t} 2=$ boletim $\& \mathrm{t} 3=\& \mathrm{t} 4=\& \mathrm{a}$ $\mathrm{r}=0 \& \mathrm{ps}=1 \&$ cachebust=1425927816515>. Accessed: May 10, 2015.

BALDI, G.; PARUELO, J.M. Land-use and land cover dynamics in South American temperate grasslands. Ecology and Society. v.13, n.2, Art.6[online]. Available from: $<$ http://www.ecologyandsociety. org/vol13/iss2/art6/>. Accessed: May 15, 2015. 2008.

BREITENBACH, R.; SOUZA, R.S de. Caracterização de mercado e estrutura de governança na cadeia produtiva do leite na 
região noroeste do Rio Grande do Sul. Organizações Rurais \& Agroindustriais, v.13, n.1, p.77-92, 2011.

CONCEIÇÃO, O.A. A expansão da soja no Rio Grande do Sul - 1950-75. 1984. 114f. Dissertação Mestrado em Economia Rural, Programa de Pós-graduação em Geografia, UFRGS, Porto Alegre, RS.

EMBRAPA. Sistema de criação de bovinos de leite para a região sudoeste do Rio Grande do Sul. 2008. Available from: $<$ http://sistemasdeproducao.cnptia.embrapa.br/FontesHTML/Leite/ BovinoLeiteRegiaoSudoesteRioGrandeSul/>. Accessed: Mar. 15, 2015.

GAS, C; GÖBEL, B. Agronegocio y desigualdades socioambientales: la soja en Argentina, Brasil y Uruguay. In: GÖBEL, B. et al. (Eds). Desigualdades socioambientales en América Latina. Bogotá: Universidad Nacional de Colômbia, 2014. 510p. p.211-254.

IBGE (INSTITUTO BRASILEIRO DE GEOGRAFIA E ESTATÍSTICA). Produção agrícola municipal. 2015. Available from: <http://www.sidra.ibge.gov.br/bda/tabela/listabl. asp? $=1612 \& z=p \& o=28>$. Accessed: Mar. 15, 2015.

IBM. IBM SPSS Statistics for Windows, Version 20.0. Armonk, NY, 2011.

JONES, H.G.; VAUGHAN, R.A. Remote sensing of vegetation: principles, techniques and applications. Oxford: Oxford University Press.2010. 353p

KOHLHEPP, G. Análise da situação da produção de etanol e biodiesel no Brasil. Estudos avançados, v.24, n.68, p.223 253. 2010. Available from: <http://dx.doi.org/10.1590/S010340142010000100017>. Accessed: Mar. 25, 2015.

LAPOLA, D.M. et al. Indirect land-use changes can overcome carbon savings from biofuels in Brazil. Proceedings of the National Academy of Sciences of the United States of America, v.107. n.8, p.3388-3393, 2010. Available from: <www.pnas.org/ cgi/doi/10.1073/pnas.0907318107>. Accessed: Mar. 15, 2015.

LAPOLA, D.M. et al. Pervasive transition of the Brazilian landuse system. Nature climate change, v.4. n.1, p.27-35, 2014. Available from: < http://www.nature.com/nclimate/journal/v4/n1/ full/nclimate2056.html>. Accessed: Mar. 10, 2015

MAIXNER, A.R. Gramíneas forrageiras perenes tropicais em sistemas de produção de leite a pasto no noroeste do Rio Grande do Sul. 2006. 74f. Dissertação (Mestrado em Zootecnia) Programa de Pós-graduação em Zootecnia, UFSM, Santa Maria, RS

MITCHELL, D.A Note on rising food prices (July 1, 2008). World Bank Policy Research Working Paper Series. 2008. Available from: <http://ssrn.com/abstract=1233058>. Accessed: Mar. 15, 2015.

MMA. Pampa. Available from: <http://www.mma.gov.br/ biomas/pampa>. Accessed: Mar. 15, 2015.

NASA. MODIS vegetation index products (NDVI and EVI) Available from: $<$ http://modis.gsfc.nasa.gov/data/dataprod/mod13. php>. Accessed: Mar, 08, 2016.

OLIVEIRA, G.; HECHT, S. Sacred groves, sacrifice zones and soy production: globalization, intensification and neo-nature in South America, Journal of Peasant Studies, v.43, n.2, p.251285, 2016. Available from: <http://www.tandfonline.com/doi/abs/
10.1080/03066150.2016.1146705>. Accessed Mar, 08, 2016. doi: $10.1080 / 03066150.2016 .1146705$.

OVERBECK, G.E. et al. Brazil's neglected biome: the south brazilian campos. Perspectives in Plant Ecology, Evolution and Systematics, v.9. p.101-116, 2007. Available from: $<$ http://ecoqua. ecologia.ufrgs.br/arquivos/Reprints\%26Manuscripts/Overbeck et_al_2007_PPEES.pdf> Accessed: Mar, 08, 2016. doi: 10.1016/ ppees.2007.07.005

Pizzato, F. Pampa gaúcho: causas e consequências do expressivo aumento das áreas de soja. 2013. 105f. Dissertação (Mestrado em Geografia) - Programa de Pós-graduação em Geografia, UFRGS. Porto Alegre, RS.

RIGHELATO, R.; SPRACKLEN, D.V. Environment. Carbon mitigation by biofuels or by saving and restoring forests? Science, v.317, n.5840, p.902, 2007. Available from: <http://www.unece. 1su.edu/biofuels/documents/20080ct/bf08_08.pdf $>$. Accessed: Mar, 08, 2016.

SANTOS, J.S. et al. Identificação da dinâmica espaço-temporal para estimarárea cultivada de soja a partir de imagens MODIS no Rio Grande do Sul. Revista Brasileira de Engenharia Agrícola e Ambiental, v.18, n.1, p.54-63, 2014. Available from: <http://www.scielo.br/ scielo.php?script=sci_arttext\&pid=S1415-43662014000100008>. Accessed: Mar, 18, 2016.

SANTOS-MARTÍN, F. et al. Unraveling the relationships between ecosystems and human wellbeing in Spain. PloS one. v.8. n.9, p. e73249. 2013. Available from: <http://journals.plos.org/plosone/ article?id=10.1371/journal.pone.0073249>. Accessed: Mar, 25, 2016 doi: 10.1371/journal.pone.0073249.

SEPLAN. Atlas Socioeconômico do Estado do Rio Grande do Sul. Porto Alegre: Secretaria do Planejamento e Desenvolvimento Regional. 2015. Available from: $<$ https://sustainabledevelopment. un.org/content/documents/Agenda21.pdf> Accessed: June 15, 2015.

SORIANO, A. et al. Río de la Plata grasslands. In: COUPLAND, R.T. (Ed.). Ecosystems of the world 8A. Natural grasslands. New York: Elsevier, 1992. p.367-407.

STEFFEN, W. et al. The Anthropocene: are humans now overwhelming the great forces of nature. AMBIO: A Journal of the Human Environment, v.36, n.8, p.614-621, 2007. Available from: <https://www.pik-potsdam.de/news/public-events/archiv/ alter-net/former-ss/2007/05-09.2007/steffen/literature/ambi-3608-06_614_621.pdf>. Accessed: Mar, 15, 2015.

UFOP. Rapeseed - Opportunity or risk for the future!? 2014. Available: <http://www.ufop.de/files/2514/2053/7975/RZ UFOP_0000_WEB_Broschure_Raps-kultur_EN.pdf $>$. Accessed: June $1 \overline{5}, 201 \overline{5}$.

VIANA, J.G.A. et al. Governance and transaction costs in the sheep production chain in Rio Grande do Sul, Brazil. African Journal of Business Management, v.6, p.4376-4385, 2012. Available from: <http://www.academicjournals.org/journal/AJBM/articlefull-text-pdf/1E6737E36642>. Accessed: May 15, 2015.

Von WITZKE, H.; NOLEPPA, S. Biofuels: Agricultural commodity prices, food security, and resource use. Agripol research paper 2014-02. 2014. Available from: <http://www.agripol-network. com/wp-content/uploads/2014/07/agripol_rp022014_2014.pdf>. Accessed: May 15, 2015. 